\section{Antibacterial activity of essential oil extracts from Curcuma xanthorrhiza roxb. rhizomes against bacteria causing pulp necrosis}

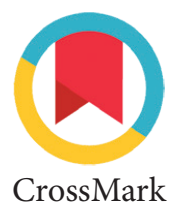

\author{
Dwi Prijatmoko, ${ }^{*}$ Nakhita L. Syafira, Pujiana E. Lestari
}

Results: The inhibition zones of $25 \%, 50 \%, 75 \%$, and $100 \%$ of temulawak rhizomes essential oil extracts against $\mathrm{E}$. faecalis were $8.17 \mathrm{~mm}, 8.54 \mathrm{~mm}, 9.53 \mathrm{~mm}$ and $10.17 \mathrm{~mm}$, respectively. Whereas, the inhibition zones of $25 \%, 50 \%, 75 \%$ and $100 \%$ of temulawak rhizomes essential oil extracts against F. nucleatum were $8.54 \mathrm{~mm}$, $8.95 \mathrm{~mm}, 9.65 \mathrm{~mm}$ and $10.75 \mathrm{~mm}$, respectively. Data analysis using Kruskal-Wallis in both of bacteria showed $p=0.00(p<0.05)$ and therefore, significant levels of inhibition.

Conclusion: Essential oil extracts from C. xanthorrhiza Roxb. rhizomes has medium antibacterial activity against $\mathrm{E}$. faecalis and $\mathrm{F}$. nucleatum.
Department of Biomedical Science, Faculty of Dentistry, Jember University, Jember, Indonesia
*Corresponding to: Dwi Prijatmoko, Department of Biomedical Science, Faculty of Dentistry, Jember University, Jember, Indonesia gawat_76.fkg@unej.ac.id

\section{Received: 3 July 2018}

Revised: 16 August 2018

Accepted: 7 November 2018

Available Online 1 December 2018

Keyword: Enterococcus faecalis, Fusobacterium nucleatum, Temulawak rhizomes essential oils, antibacterial activity Cite this Article: Prijatmoko D, Syafira NL, Lestari FE. 2018. Antibacterial activity of essential oil extracts from Curcuma xanthorrhiza roxb. rhizomes against bacteria causing pulp necrosis. Journal of Dentomaxillofacial Science 3(3): 144-148. D0I: 10.15562/jdmfs.v3i3.763

\section{Introduction}

Pulp necrosis (98.5\%) involves the invasion of intracanal bacterias and its products. ${ }^{1,2}$ Failure in root canal treatment is possibly due to the fact that those microorganisms are persistent and recolonize within the canal. ${ }^{3}$ Root canal infection is a polymicrobial infection involving both gram-positive and gram-negative anaerobic bacteria. The most common microorganisms found in root canal infections are Enterococcus faecalis and fusobacterium nucleatum, respectively as gram-positive and negative bacteria. ${ }^{5,6}$

Chlorophenol Kamfer Menthol (ChKM) and Cresophene are commonly used for root canal sterilization. However, ChKM and Cresophene are reported to reduce the viability of fibroblast cells. ${ }^{7,8}$ Therefore, it suggested to find other environmentally friendly potential drugs, such as a herbal medicine, as an alternative for root canal sterilization with minimal side effects.

One of the herbal medicine that can be used is temulawak rhizomes. Temulawak (Curcuma xanthorrhiza Roxb.) is a plant originating from the Indo-Malaysia region. Temulawak rhizome is reported to contain essential oil, in about 4-6\% abundance. ${ }^{9}$ The largest active compound that constitutes the essential oil of the temulawak rhizomes is xanthorrhizol. Xanthorrhizol is only found in temulawak and turmeric. Xanthorrhizol is an excellent antibacterial agent at high temperatures $\left(121^{\circ} \mathrm{C}, 15\right.$ minutes $)$ and in extreme $\mathrm{pH}$, both acid and base. Xanthorrhizol works by disrupting the formation of biofilms from oral cavity bacteria. $^{10}$

The purpose of this study is to determine the potential antibacterial activity of essential oil extracts of temulawak rhizomes to E. faecalis and F. nucleatum.

\section{Material and Methods}

This is a laboratory experimental study with posttest only control group design. This experimental study consist of 4 concentrations of extracts of temulawak rhizomes by diluting the essential oil using $10 \%$ DMSO and $0.5 \%$ Tween 80 (pure 100\%, $75 \%, 50 \%, 25 \%), 2$ positive control groups (ChKM and Cresophene) and a negative control group (10\% Dimethyl Sulfoxide and 0.5\% Tween 80).

The antibacterial test used was disc-diffusion method on the MH-A media (Mueller Hinton Agar). The antibacterial test and the inhibitory zone diameter measurements were performed according to the standard protocol of the National Committee for Clinical Laboratory Standards (NCCLS). ${ }^{11}$ 


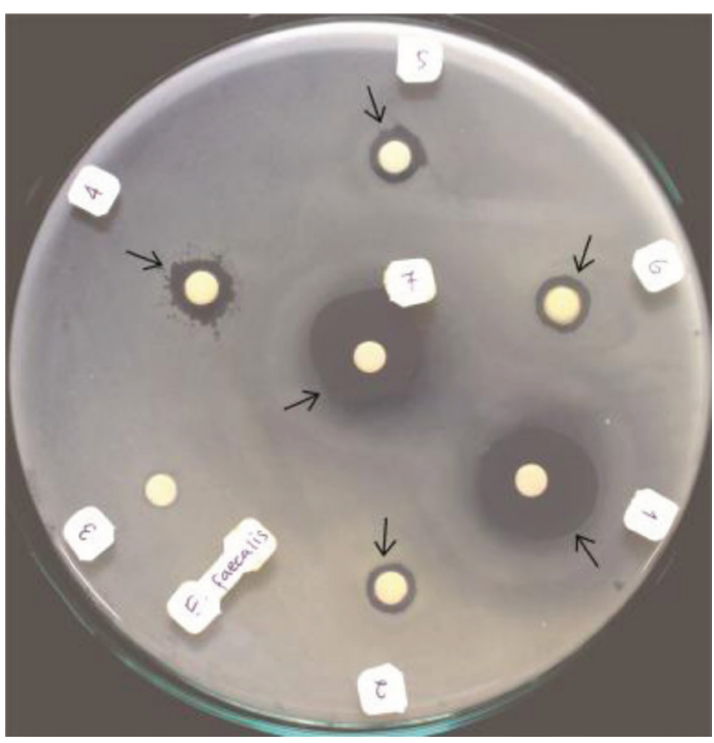

Figure 1 Disc-diffusion test results against E. faecalis showed clear inhibition zones around the disk (arrows)

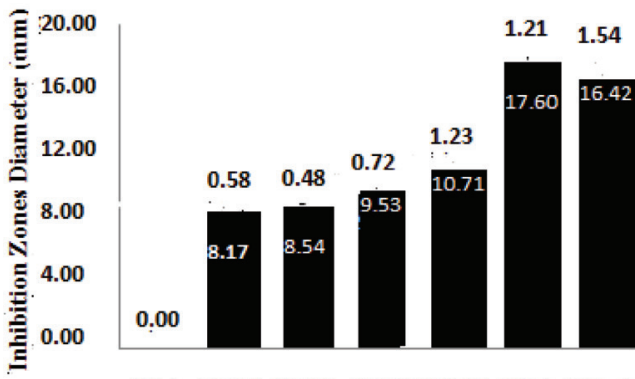

K(-) RT25 RT50 RT75 RT100 K(+) K(+) Treatment Groups

K(-): Negative control (10\% Dimethyl Sulfoxide (DMSO) $+0.5 \%$ Tween 80 )

RT25: Essential oil extracts of temulawak rhizomes with concentration of $25 \%$

RT50: Essential oil extracts of temulawak rhizomes with concentration of $50 \%$

RT75: Essential oil extracts of temulawak rhizomes with concentration of $75 \%$

RT100: Essential oil extracts of temulawak rhizomes with concentration of $100 \%$

$\mathrm{K}(+)$ positive control (ChKM)

$\mathrm{K}(+)$ : positive control (Cresophene)

Figure 2 The average value of inhibition zone diameter essential oil extracts of temulawak rhizomes against E. faecalisatseveral concentrations: $25 \%$ (RT25), 50\% (RT50), 75\% (RT75), 100\% (RT100), 10\% Dimethyl Sulfoxide $(\mathrm{DMSO})+0.5 \%$ Tween 80 as negative control $(\mathrm{K}(-))$, ChKM as positive control $(\mathrm{K}(+))$ and Cresophene as positive control $(\mathrm{K}(++))$
Data analysis used was non-parametric statistical test Kruskal-Wallis which is then continued with Mann-Whitney test to know the differences among the research groups. p-value used for Kruskal-Wallis and Mann-Whitney test in this study was 0.05 .

\section{Results}

The disc diffusion test results from the essential oil extracts of temulawak rhizomes (C. xanthorrhiza Roxb.) against E. faecalis showed clear inhibition zones around the disk, which can be seen in figure 1.

The average value of inhibition zone diameter against $\mathrm{E}$. faecalis was presented in figure 2.

The result of data analysis using Kruskal-Wallis test returned a significance value of data $p=0.00$ $(p<0.05)$. This data showed that the essential oil extracts of temulawak rhizomes had antibacterial activity against E. faecalis. Data analysis was then continued using Mann-Whitney test to find out which research groups were different. MannWhitney test results showed that there were significant differences between all treatment groups with negative control group, $25 \%$ concentration group with concentration of $75 \%$ and $100 \%$, and $50 \%$ concentration group with $100 \%$.

The disc-diffusion test results from the essential oil extracts of temulawak rhizomes (C. xanthorrhiza Roxb.) against F. nucleatum showed clear inhibition zones around the disk, which can be seen in figure 3.

The average value of inhibition zone diameter against $F$. nucleatum was presented in figure 4.

The result of data analysis using Kruskal-Wallis test returned a significance value of data $\mathrm{p}=0.00$ $(p<0.05)$. This data showed that the essential oil extracts of temulawak rhizomes had antibacterial activity against F. nucleatum. Data analysis was then continued using Mann-Whitney test to find out which research groups were different. MannWhitney test results showed that there were significant differences among all treatment groups $25 \%, 50 \%, 75 \%$ and $100 \%$.

\section{Discussion}

This research used the essential oil of temulawak rhizomes with concentrations of $25 \%, 50 \%, 75 \%$, and $100 \%$. Essential oils of temulawak rhizomes in this research were diluted using $10 \%$ DMSO and $0.5 \%$ Tween 80 . The solvent was reported to have no antibacterial activity against gram-positive and gram-negative bacteria, which did not affect the results of the study. ${ }^{12-14}$ Tween $80(0.5 \%)$ was used 


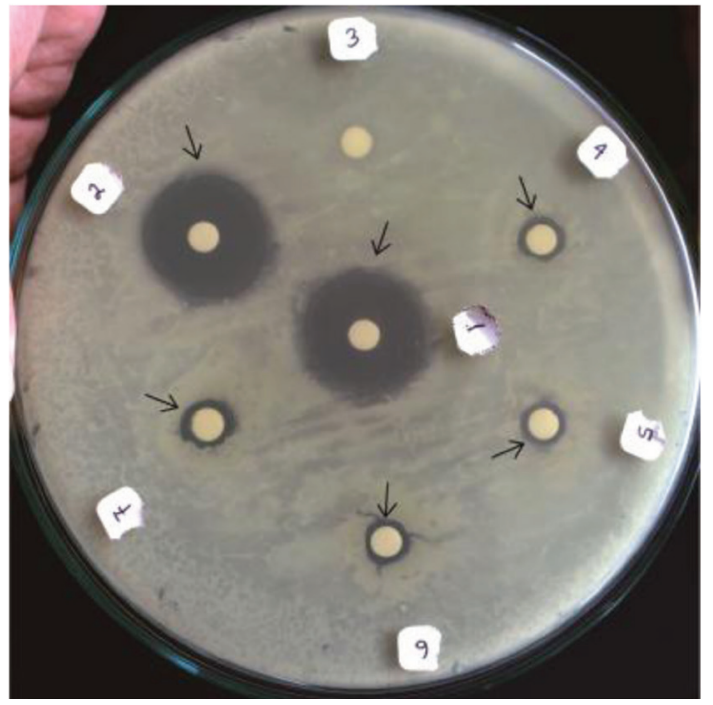

Figure 3 Disc-diffusion test results against $\mathrm{F}$. nucleatum showed clear inhibition zones around the disk (arrows)

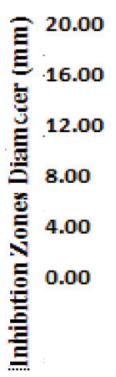

$\mathrm{K}(-)$ :

RT25: Essential oil extracts of temulawak rhizomes with concentration of $25 \%$

RT50: Essential oil extracts of temulawak rhizomes with concentration of $50 \%$

RT75: Essential oil extracts of temulawak rhizomes with concentration of $75 \%$

RT100: Essential oil extracts of temulawak rhizomes with concentration of $100 \%$

$\mathrm{K}(+)$ : Positive control (ChKM)

$\mathrm{K}(+)$ : Positive control (Cresophene)

Figure 4 The average value of inhibition zone diameter essential oil extracts of temulawak rhizomes against $\mathrm{F}$. nucleatum at several concentrations: 25\% (RT25), 50\%(RT50), 75\% (RT75), 100\% (RT100), 10\% Dimethyl Sulfoxide (DMSO) $+0.5 \%$ Tween 80 as negative control (K(-)), ChKM as positive control $(\mathrm{K}(+))$ and Cresophene as positive control $(\mathrm{K}(++))$ as an emulsifier for water and oil to be homogeneous. Tween 80 is a fatty acid ester of polysorbate 80 or polyoxyethylene 20 sorbitan monooleate $\left(\mathrm{C}_{64} \mathrm{H}_{124} \mathrm{O}_{26}\right)$. The advantage of Tween 80 as an emulsifier is that it can stabilize the emulsion system and its solubility is high in water, oil, ethanol, and organic solvents. ${ }^{15}$

Antibacterial activity of essential oil extracts of temulawak rhizomes is directly related to the active compounds that constitute them. Xanthorrhizol is the main compound of the essential oil of temulawak rhizomes. The rest, in small amounts, are composed of camphene, curcumin, $\alpha$-Pinene, $\beta$-curcumene, zingiberene, $\alpha$-thujene, $\beta$-pinene, myrcene, linalool, $\beta$-bisabolol, and ar-curcumene. ${ }^{14,16,17}$ Ninety-two percent of essential oils of temulawak rhizomes are largely composed of terpene classes, particularly sesquiterpenes and derivatives of other oxygenated compounds. ${ }^{16}$ Previous studies using other herbals can also inhibit the growth of gram-positive and gram-negative bacteria where the results are consistent with this study. Indriana et al. ${ }^{18}$ conducted a study using Hibiscus sabdariffa ethanol extract reportedly proven to inhibit the growth of Porphyromonas gingivalis and Streptococcus sanguis. Another study by Tanumihardja et al. ${ }^{19}$ using ethanol root extract of Sida rhombifolia was also shown to inhibit E. faecalis and Actinomyces spp.

Terpene is a hydrocarbon chain formed through the combination of several isoprene units $\left(\mathrm{C}_{5} \mathrm{H}_{8}\right) .^{20}$ Terpene and other oxygenated compounds are hydrophobic or lipophilic, which can typically enter the membrane structure. This leads to expansion of the cell membrane causing in increased fluidity and permeability of membrane that eventually leads to bacterial cell lysis. ${ }^{20-22}$ Terpene antibacterial activity also involves the destruction of transmembrane proteins, respiratory inhibition, and changes in ion transport processes. ${ }^{23}$ Generally, the main target of the terpene is the bacterial cell membrane. ${ }^{15}$

The antibacterial activity of essential oil of temulawak rhizomes can be classified based on its inhibition zone diameter. Ponce et al. ${ }^{23}$ classifies antibacterial activity into 4 levels, those are weak (not sensitive), moderate (sensitive), strong (very sensitive) and very strong (extremely sensitive). Antibacterial activity is said to be weak if the inhibition zone diameter is $<8 \mathrm{~mm}$, moderate is $8-14 \mathrm{~mm}$, strong is $15-19 \mathrm{~mm}$, and very strong if $>20 \mathrm{~mm}$. The classification of Ponce et al. ${ }^{23}$ has been widely used by researchers in comparing the antibacterial activity of an extracts, as in the studies conducted by Celikel et al. ${ }^{24}$ Zenati et al. ${ }^{25}$ Cherfia et al. ${ }^{26}$ and Ed-Dra et al. ${ }^{27}$ 
The inhibition zone diameter of essential oil extracts of temulawak rhizome against E. faecalis and $\mathrm{F}$. nucleatum at all concentrations was in the range of 8-11 mm. According to the classification of Ponce et al. ${ }^{23}$ all four of these concentrations have moderate-level antibacterial properties in both bacteria.

Research on the antibacterial activity of essential oils extracts of temulawak rhizomes against gram-positive and gram-negative bacteria has also been done. A study conducted by Lopez-Romero et al. ${ }^{15}$ reported that gram-positive bacteria were more resistant to essential oils than gram-negative bacteria, in line with studies conducted by Prabuseenivasan et al. ${ }^{14}$ and Borges et al. ${ }^{28}$ This is in contrast to what reported by Sylvester et al. ${ }^{14}$ in his journal that gram-negative bacteria are more resistant than gram-positive bacteria, in line with previous studies by Zaidan et al. ${ }^{29}$ Gangoué-Piéboji et al. ${ }^{30}$ and Hafidh et al. ${ }^{31}$

The antibacterial activity of essential oil extracts of temulawak rhizomes are slightly different in gram-positive and gram-negative bacteria due to different membrane structure and cell walls. Gram-negative bacteria are composed of thin peptidoglycan layers adjacent to the cytoplasmic membrane and outer membrane (OM), whereas gram-positive bacteria have a thicker peptidoglycan layer but do not have an outer membrane. ${ }^{13,14}$ The outer membrane of the gram-negative bacteria is constructed by phospholipids and lipopolysaccharides and forms a hydrophilic permeability barrier that provides protection against hydrophobic antibacterial agents. ${ }^{19}$ On the other hand, although gram-positive bacteria have no outer membrane, the bacterial cell wall is formed by a thick layer of peptidoglycan, making it difficult to penetrate by a antimicrobial and more resistant to turgor pressure and permeability changes. ${ }^{13}$

The antibacterial activity of essential oil extracts of temulawak rhizomes is not only influenced by the active compound contained in it, but is also influenced by the membrane structure and cell wall of bacteria. ${ }^{14,18}$ There are several other things that also affect its antibacterial activity, including the chain construction of the essential oil active compounds, physicochemicals and the bacterial cell surface tension, the releasing of $\mathrm{K}+$ ions, and the bacterial cell form. ${ }^{13}$ These may be the reasons why essential oil extracts of temulawak rhizomes are effective against gram-negative and gram-positive bacteria.

The concentration of essential oil extracts of temulawak rhizomes used in this study refers to the research done by Prabuseenivasan et al. ${ }^{12}$ those are 25\%, 50\%, 75\% and 100\%. Essential oil with 100\% concentration has greater antibacterial activity than concentrations of $75 \%, 50 \%$ and $25 \%$ in both bacteria. This is in line with research conducted by Prabuseenivasan et al. ${ }^{12}$ and Jantan et al. ${ }^{16}$ that the essential oil extracts of temulawak rhizomes will work better at higher concentrations.

This study used ChKM and cresophene as positive controls. Both materials are selected because they have been commonly used as root canal sterilization. The inhibition zone diameter of ChKM and cresophene on E. faecalis is in the range of $16-17 \mathrm{~mm}$, while on $\mathrm{F}$. nucleatum in the range of $18-19 \mathrm{~mm}$. Referring to the classification of Ponce et al. ${ }^{21}$ antibacterial activity of ChKM and Cresophene are strong in both bacteria.

Further research needs to be done to optimize the antibacterial activity of the essential oil extracts of temulawak rhizome in order to be a comparable product to those that already exist on the market. Optimization may including extracting a single active compound from the essential oil of the temulawak rhizomes or increasing the potentiation by a combination of two herbal medicines. Thus, this study can be used as an alternative to root canal sterilization with minimal side effects.

\section{Conclusion}

The essential oil extracts of temulawak rhizomes (C. xanthorrhiza Roxb.) has antibacterial activity against bacteria causing pulp necrosis, E. faecalis and F. nucleatum. The four concentrations of essential oils of temulawak rhizomes, 25\%, 50\%, 75\% and $100 \%$, have inhibition zones diameter in the range of $8-11 \mathrm{~mm}$ against $\mathrm{E}$. faecalis and $\mathrm{F}$. nucleatum. The antibacterial activity of essential oil extracts of temulawak rhizomes is in the medium level.

\section{Acknowledgment}

The author would like to express sincere thanks to all students of the Faculty of Dentistry, Jember University for providing active participation during this research process.

\section{Conflict of Interest}

The authors report no conflict of interest.

\section{References}

1. Garg N, Garg A. Textbook of endodontics. 3rd ed. New Delhi: Jaypee Brothers Medical Publishers; 2013.

2. Ubele VDV. Purpose and problems of periodontal disease classification. Periontol 2000 2005;39: 13-21.

3. Asgary S, Marvasti LA. Necrosis of intact premolar caused by an adjacent apical infection: a case report. Restor Dent Endod 2013;38: 90-92.

4. Zehnder M. Root canal irrigants. J Endod 2006;32: 389-398. 
5. Guimarães NLSL, Otoch HM, de-Andrade LC, et al. Microbiological evaluation of infected root canals and their correlation with pain. RSBO 2012;9: 31-37.

6. Shan T, Khan I, Hussain W, et al. Frequency of enterococcus faecalis in saliva and root canals with treatment failure. Pak Armed Forces Med J 2014;64: 395-398.

7. Dammaschke T, Jung N, Harks I, et al. The effect of different root canal medicaments on the elimination of Enterococcus faecalis ex vivo. Euro J Dentist 2013;7: 442-448.

8. Gheorghiu IM, Suciu I, Marian VC, et al. Biological effects of endodontic medication on human fibroblast cell culture. Proc Rom Acad Series B 2014;16: 33-37.

9. Setyawan AD. Keanekaragaman kandungan minyak atsiri rimpang temu-temuan (Curcuma). Biofarmasi 2003;1: 44-49.

10. Lee YL, Shim JS, Rukayadi Y, et al. Research note: antibacterial activity of xanthorrhizol isolated from Curcuma xanthorrhiza roxb. against foodborne pathogens. J Food Protec 2008;71: 1926-1930.

11. Gary CA. Periodontal diagnoses and classification of periodontal diseases. Periodontol 2000 2004;34: 9-21.

12. Prabuseenivasan $S$, Jayakumar M, Ignacimuthu S. Research article: In vitro antibacterial activity of some plant essential oils. BMC Complement \& Altern Med 2006;6: 1-8.

13. Lopez-Romero JC, González-Ríos H, Borges A, et al. Research article antibacterial effects and mode of action of selected essential oils components against escherichia coli and staphylococcus aureus. Evid Based Complementary Altern Med 2015;795435: 1-9.

14. Sylvester WS, Son R, Lew KF, et al. Antibacterial activity of Java turmeric (Curcuma xanthorrhiza roxb.) extracts against klebsiella pneumoniae isolated from several vegetables. Int Food Res J 2015;22: 1770-1776.

15. Frank AS, Renee BB, Susanna P. Associations between periodontal disease and risk for atherosclerosis, cardiovascular disease and stroke. A systematic review. Ann Periodontol Bann 2003;8: 38-53.

16. Jantan I, Saputri FC, Qaisar MN, et al. Research article: correlation between chemical composition of Curcuma domestica and Curcuma xanthorrhiza and their antioxidant effect on human low-density lipoprotein oxidation. Evid Based Complementary Altern Med 2012;438356: 1-10.

17. Jeeva SPA, Helen M, Gomathy SS, et al. Phytochemical characterization and antimicrobial activity of Curcuma xanthorrhiza roxb. Asian Pacific J Tropic Biomed 2012: S637-S640.

18. Indriani L, Dharmautama M. Antimicrobial test of roselle (hibiscus sabdariffa 1.) ethanol extract againts porphyromonas gingivalis and Streptococcus sanguis using agar method (in vitro study). J Dentomaxillofac Sci 2016;1: 134-138.
19. Tanumihardja M, Darmayana, Natsir N, et al. Aktivitas antibakteri ekstrak terstandar akar sidaguri (S.rhombifolia) terhadap E. faecalis dan Actinomyces spp. J Dentomaxillofac Sci 2013;12: 90-94.

20. Nazzaro F, Fratianni F, Martino LD, et al. Review: effect of essential oils on pathogenic bacteria. Pharmaceuticals 2013;6: 1451-1474.

21. Trombetta D, Castelli F, Sarpietro MG, et al. Mechanisms of antibacterial action of three monoterpenes. antimicrob. Agents Chemother 2005;49: 2474-2478.

22. Zengin H, Baysal AH. Antibacterial and Antioxidant Activity of Essential Oil Terpenes agains Pathogenic and Spoilage-Forming Bacteria and Cell Structure-Activity Relationships Evaluated by SEM Microscopy. Molecules 2014;19: 17773-17798.

23. Ponce AG, Fritz R, del-Valle C, et al. Antimicrobial activity of essential oils on the native microflora of organic Swiss chard. Lebensm Wiss-u Technol 2003;36: 679-684.

24. Celikel N, Kavas G. Antimicrobial properties of some essential oils against some pathogenic microorganisms. Czech J Food Sci 2008;26: 174-181.

25. Zenati F, Benbelaid F, Khadir A, et al. Antimicrobial effects of three essential oils on multidrug resistant bacteria responsible for urinary infections. J Appl Pharmac Sci 2014;4: 15-18.

26. Cherfia R, Ali MK, Talhi I, et al. Phytochemical analysis, antioxidant and antimicrobial activities of leaves and flower ethyl acetate and n-butanol fractions from algerian endemic plant calycotome spinosa (L.) Link. J Pharmacognosy \& Phytother 2017;9: 185-196.

27. Ed-Dra A, Filai FR, Bou-Idra M, et al. Application of mentha suaveolens essential oil as an antimicrobial agent in fresh turkey sausages. J Appl Biol \& Biotechnol 2018;6: 7-12.

28. Borges A, Saavedra MJ, Simões M. The activity of ferulic and gallic acids in biofilmprevention and control of pathogenic bacteria. Biofouling 2013;28: 755-767.

29. Zaidan MR, Rain AN, Badrul AR, et al. In vitro screening of five local medicinal plants for antibacterial activity using disc diffusion method. Tropic Biomed 2005;22: 165-170.

30. Gangoue-Pieboji J, Eze N, Djintchui AN, et al. The in-vitro antimicrobial activity of some medicinal plants against $\beta$-lactam- resistant bacteria. J Infect Develop Countries 2009;3: 671-680.

31. Hafidh RR, Abdulamir AS, Vern LS, et al. Inhibition of growth of highly resistant bacterial and fungal pathogens by a natural product. The Open Microbiol 2011;5: 96-106.

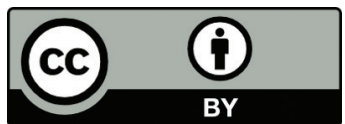

This work is licensed under a Creative Commons Attribution 